\title{
WEIGHT DISCRIMINATION IN THE LABOUR LAW
}

IŞ HUKUKUNDA KILO AYRIMCILIĞI

\section{Hakemli Makale \\ Doğukan KÜÇÜK*}

TABLE OF CONTENTS

INTRODUCTION ..............................................................................................................................................517

I. LEGAL BASES OF EQUALITY AND PROHIBITION OF WEIGHT

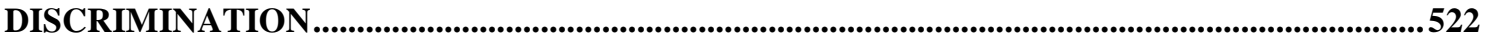

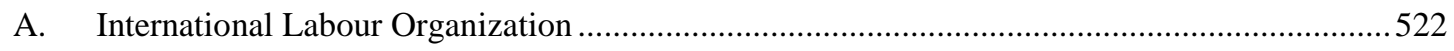

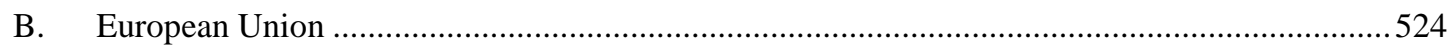

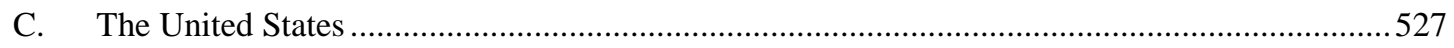

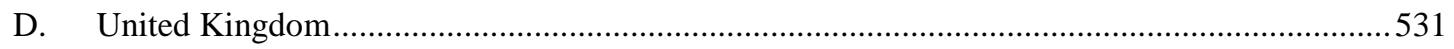

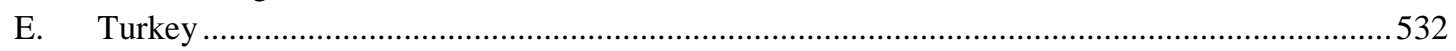

II. WEIGHT DISCRIMINATION IN TURKISH LABOUR LAW ..............................................535

III. CAN OBESITY BE CONSIDERED AS A DISABILITY IN TURKISH LABOUR LAW?..540

IV. WEIGHT DISCRIMINATION IN THE LIGHT OF COURT DECISIONS ...........................542

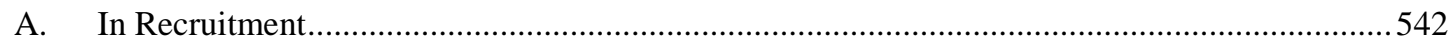

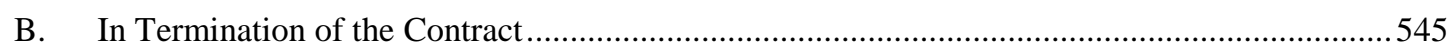

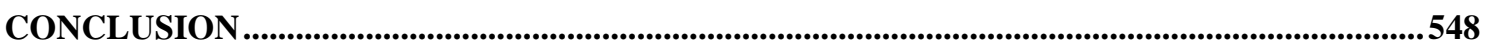

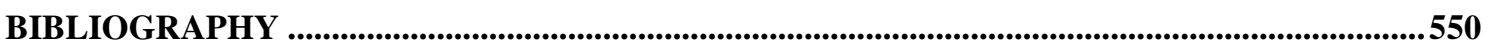

DOI: $10.32957 /$ hacettepehdf.894561

Makalenin Geliş Tarihi: 23.09.2020 Makalenin Kabul Tarihi: 13.04.2021

* Res. Asst. Anadolu University, Faculty of Law. E-mail: dogukankucuk@anadolu.edu.tr

ORCID: 0000-0002-3024-6285

The principles of research and publication ethics were followed in the article. 


\begin{abstract}
In 2010, it was reported in the news that Turkish Airlines forced twenty-eight cabin crews to take a sixmonth unpaid leave to lose weight because they could not maintain their weight ratio. A similar practice was also seen in Air India company in recent years. For example, in 2019, some cabin crews at Air India company were forced to a low-calorie diet to maintain "normal weight"; in 2015, some cabin crews were asked to lose weight. Practices such as termination of employment contracts, unpaid leave, assignment to another job, low wages, not being promoted due to weight are observed not only in the aviation sector but also in all areas of working life. Employees or applicants who are overweight or underweight may face various discriminatory behaviors in their working lives due to their weight. In this context, the employer's duty of equal treatment and non-discrimination needs to be considered in terms of the employee's weight.
\end{abstract}

Keywords: Discrimination, weight, the duty of equal treatment, disability, labour law

öz

2010 yılında Türk Hava Yolları'nın yirmi sekiz kabin görevlisini, kilo oranlarını koruyamadıkları gerekçesiyle, kilo vermeleri için altı aylık ücretsiz izne ayırmaya zorladığı yolundaki haberler basında yer almıştır. Benzer bir uygulamanın son yıllarda Air India şirketi tarafından da yapıldığı görülmüştür. Örneğin 2019 yılında Air India kabin görevlileri şişmanlamamaları için düşük kalori diyetine tâbi tutulmuşlar; 2015 yılında ise bazı kabin görevlilerinin zayıflaması istenmiştir. Kilo nedeniyle iş sözleşmesinin feshi, ücretsiz izin, başka işte görevlendirme, düşük ücret ödenmesi, terfi ettirilmeme gibi uygulamalar sadece havacılık sektöründe değil, çalışma hayatının her alanında gözlemlenmektedir. Aşırı kilolu ya da aşırı zayıf olan işçiler ya da aday işçiler, kiloları nedeniyle çalışma yaşamlarında çeşitli ayrımcı davranışlarla karşı karşıya kalabilmektedir. Bu bağlamda işverenin eşit davranma ve ayrımcılık yapmama borcunun işçinin kilosu çerçevesinde de düşünülmesi gereklidir.

Anahtar Kelimeler: Ayrımcılık, kilo, eşit işlem borcu, engellilik, iş hukuku

\title{
INTRODUCTION
}

World Health Organization (WHO) describes overweight and obesity as abnormal or excessive fat accumulation. ${ }^{1}$ For determining who is overweight or obese, WHO has formed an index called body mass index (BMI). ${ }^{2}$ What makes excessive fat accumulation

1 https://www.who.int/topics/obesity/en/, (date of access 7.8.2020).

2 BMI is calculated by dividing a person's weight in kilograms by the square of their height in meters. For adults, if someone's BMI is equal to or greater than 25 , he/she is overweight. If the BMI is higher than or equal to 30 , he/she is obese; and if it is +40 , he/she is morbidly obese. 
so vital is its impact on health. Being obese or overweight is considered an essential risk factor for health and can cause significant health problems. ${ }^{3}$ They increase the risk of cardiovascular diseases, hypertension, musculoskeletal disorders, diabetes, some cancers such as liver, kidney or colon. ${ }^{4}$

Although the harmful effects of fat accumulation on the body are known, the number of "obese" increases day by day. According to the Global Health Observatory data of the WHO, in 2016, 39\% of women and men are overweight. ${ }^{5}$ Similarly, another survey conducted by the Turkish Statistical Institute (known as TurkStat) shows that, in 2019, $\% 24,8$ of women and \%17,3 of men are obese individuals; also \%30,4 of women and $\% 39,7$ of men are overweight individuals in Turkey. ${ }^{6}$

As the number of obese and overweight people increases, health expenditures also rise, which have adverse effects on the economy. ${ }^{7}$ For example, in developed economies, between two and seven percent of all healthcare spending is due to obesity, and the global economic impact of obesity is estimated to be around 2.0 trillion dollars. ${ }^{8}$ Besides the impacts on health and economy, obesity and overweight may lead to some consequences in social relationships. Obese or overweight individuals are frequently stereotyped as lazy, unintelligent, lacking in self-control, ugly, unhappy, and undisciplined. ${ }^{9}$ On the

https://www.who.int/en/news-room/fact-sheets/detail/obesity-and-overweight, (date of access 22.7.2020).

3 BIERMAN Jr., Donald L., "Employment Discrimination Against Overweight Individuals: Should Obesity Be Protected Classification”, Santa Clara Law Review, Year: 1990, Volume: 30, Issue: 4, (p. 951-976), p. 957.

4 KUBOTA, Luis Claudio, "Discrimination Against the Obese and Very Thin Students in Brazilian Schools", Institute for Applied Economic Research, Discussion Paper 199, 2015, p. 7, http://repositorio.ipea.gov.br/bitstream/11058/5138/1/DiscussionPaper_199.pdf, (date of access 10.9.2020).

5 https://www.who.int/gho/ncd/risk_factors/overweight/en/, (date of access 24.7.2020).

6 http://www.tuik.gov.tr/PreHaberBultenleri.do?id=33661, (date of access 24.7.2020).

7 MASON, Katherine, "The Unequal Weight of Discrimination: Gender, Body Size, and Income Inequality”, Social Problems, Year: 2015, Volume: 59, Issue: 3, (p. 411-435), p. 411.

8 BAJOREK, Zofia / BEVAN, Stephen, "Obesity and Work Challenging Stigma and Discrimination”, Institute for Employment Issue, Year: 2019, Report: 526, p. 4.

https://www.employment-studies.co.uk/system/files/resources/files/526.pdf, (date of access 22.8.2020).

9 CHERNOV, Andrea E., "Weight Discrimination: The Effects of Obesity on Employment and Promotion”, University of Hawaii Hohonu, Year: 2006, Issue: 6, (p. 107-113), p. 107; WANG, Lucy, 
other hand, societies also regularly consider them that they become obese willingly. ${ }^{10}$ These prejudices are mostly shaped by "white male" of society. "White male" norms, which are very effective, determine codes about grooming, appearance or dressing.

These codes also cause one of the main problems in society: Discrimination. As a type of discrimination, appearance discrimination means treating someone unfairly for no just cause or valid reason due to her/his physical appearance such as weight, height, skin color, being attractive or unattractive, or grooming and dressing style such as religious dressing, dressing feminine, dressing masculine, growing beard, tattoos, and piercings. ${ }^{12}$

Weight discrimination as a subtype of appearance discrimination is a widespread form of discrimination. Not only in society but also in workplaces individuals may encounter weight discrimination. ${ }^{13}$ For example, in 2010, the media reported that Turkish

“Weight Discrimination: One Size Fits All Remedy?”, The Yale Law Journal, Year: 2008, Issue: 117, (p. 1900-1945), p. 1902; SIZEMORE, Steven C., "Fatter Butt Equals a Skinnier Wallet: Why Workplace Wellness Programs Discriminate Against the Obese and Violate Federal Employment Law", Wyoming Law Review, Year: 2011, Volume: 11, Issue: 2, (p. 639-668), p. 640; PUHL, Rebecca M. / DEPIERRE, Jenny A., "Appearance Discrimination and The Law”, Encyclopedia of Body Image and Human Appearance, Year: 2012, Volume: 1, (p. 30-35), p 30; O’BRIEN, Kerry Steven / LATNER, Janet / EBNETER, Daria et al., "Obesity Discrimination: The Role of Physical Appearance, Personal Ideology, and Anti-Fat Prejudice”, International Journal of Obesity, Year: 2013, Issue: 37, (p. 455446), p. 455.

10 BIERMAN, 1990, p. 957.

11 It is expressed that prejudices about weight are associated with authoritarianism and social dominance orientation. O'BRIEN / LATNER / EBNETER et al., 2003, p. 456.

12 MALOS, Stan, “Appearance-Based Sex Discrimination and Stereotyping in the Workplace: Whose Conduct Should We Regulate?”, Employee Responsibilities Rights Journal, Year: 2007, Issue: 19, (p. 95-111), p. 96; RHODE, Deborah L., "The Injustice of Appearance”, Stanford Law Review, Year: 2009, Volume: 61, Issue: 5, (p. 1033-1102), p. 1037; HUXLEY, Caroline, "Lesbian and Bisexual Women's Experiences of Sexuality-Based Discrimination and Their Appearance Concern", Psychology \& Sexuality, Year: 2012, Volume: 4, Issue: 1, (p. 7-15), p. 7; ILO, Discrimination at Work on the basis of Sexual Orientation and Gender Identity: Results of Pilot Research, International Labour Office, Governing Body, 319th Session, Genova, 2013, p. 2. https://www.ilo.org/wcmsp5/groups/public/---ed_norm/---

relconf/documents/meetingdocument/wcms_221728.pdf, (date of access 29.8.2020); LEE, Hyemin / SON, Inseo / YOON, Jaehong et al., "Lookism Hurts: Appearance Discrimination and Self-Rated Health in South Korea" International Journal for Equity in Health, Year: 2017, Issue: 16, (p. 204210), p. 204.

13 VIVIERS, Damien Jr., A Comparative Labour Law Perspective on Categories of AppearanceBased Prejudice in Employment, Unpublished Thesis (LL.M), University of the Free State, 2014, p. 118; HUGGINS, Michael L., "Not Fit for Hire: The United States and France on Weight Discrimination in Employment”, Fordham International Law Journal, Year: 2015, Volume: 38, Issue: 3, (p. 889951), p. 904. 
Airlines forced twenty-eight cabin crews to take six-month unpaid leave to lose weight because they could not maintain their weight ratio. ${ }^{14}$ According to Turkish Airlines' manager's statement in the same news, it is emphasized that "The criteria for weight and height are important factors in all airlines. These criteria are important in terms of both visuality and mobility in this profession". Likewise, in 2019, cabin crews at Air India company were forced to go on a low-calorie diet to maintain normal weight; in 2015 in the same company, some cabin crews were asked to lose weight ${ }^{15}$; in 2009 , some cabin crews were fired because they were overweight ${ }^{16}$.

It is observed that obese individuals are treated "differently" compared to nonobese ones at recruitment, applying the work conditions such as promotion and paying wages, or termination of the contract. ${ }^{17}$ Employers have tendencies to hire good-looking applicants, especially those who are going to be the face of the business, due to the belief that physical appearance impresses customers. Also, employers have biases that they are healthier, more hardworking than obese or overweight individuals. ${ }^{18}$ Due to the "fat 19 employees" are seen as unhealthy and less profitable, employers are adapting programs

14 https://www.haberturk.com/ekonomi/airport/haber/539824-sisman-hostes-yasak., (date of access 9.10.2020).

15 https://edition.cnn.com/travel/article/air-india-staff-diet-intl-scli/index.html., (date of access 9.10.2020).

16 https://www.nytimes.com/2009/01/07/world/asia/07briefs-9FLIGHTATTEN_BRF.html, (date of access 5.4.2021).

17 GARCIA, Jeffrey, "Weight-Based Discrimination and the Americans With Disability Act: Is There an End in Sight?”, Hofstra Labor and Employment Law Journal, Year: 1995, Volume: 13, Issue: 1, (p. 1-30), p. 2; KRISTEN, Elizabeth, "Addressing the Problem of Weight Discrimination in Employment", California Law Review, Year: 2002, Issue: 90, Volume: 1, (p. 57-110), p. 60 ff.; SWAMI, Viren / WONG, Vivien / FURNHAM, Adrian et. all, "Weight-Based Discrimination in Occupational Hiring and Helping Behavior", Journal of Applied Social Psychology, Year: 2008, Volume: 38, Issue: 4, (p. 968-981), p. 977; FLINT, Stuart W. / CODREANU, Sonia C. / GOMOIU, Amalia et al., "Obesity Discrimination in the Workplace: "You're Hired!'”, Journal of European Psychology Students, Year: 2015, Volume: 6, Issue: 2, (p. 64-69), p. 64; O’BRIEN / LATNER / EBNETER et al., 2003, p. 456; KUBOTA, 2015, p. 7.

18 CAVICO, Frank J. / MUFFLER, Stephen C. / MUJTABA, Bahaudin G., "Appearance Discrimination, "Lookism" and "Lookphobia" in the Workplace", The Journal of Applied Business Research, Year: 2012, Volume: 28, Issue: 5, (p. 791-802), p. 792; CHERNOV, 2006, p. 108; BAJOREK / BEVAN, 2019, p. 13.

19 The word "fat" is considered more offensive than obese or overweight. RHODE, 2009, p. 1036. 
to reduce expenses by not hiring them. ${ }^{20}$ For example, a survey conducted in the UK shows that $45 \%$ of British employers are less likely to recruit an obese applicant at the interview stage. ${ }^{21}$ Another study in Sweden shows that obese applicants receive 20 percent fewer callbacks for an interview than non-obese applicants. ${ }^{22}$ In parallel with this, the level of unemployment rate among obese individuals is higher than normal-weight individuals. $^{23}$

Not only overweight and obese individuals but also emaciated or underweight individuals are likely to be discriminated against in social life and the workplace. ${ }^{24} \mathrm{~A}$ study shows us that emaciated individuals may face similar levels of discrimination as overweight individuals. ${ }^{25}$ It also shows us that all people who have not normal-weight are the victim of "what is beautiful is good" stereotype. ${ }^{26}$ In this context, weight discrimination is not only related to overweight or obesity but may also arise in terms of underweight.

In the case of Laffey v. Northwest Airlines, Inc. ${ }^{27}$, the qualifications and requirements of female cabin attendants have been determined differently than their male

20 MAHAJAN, Ritu, "The Naked Truth: Appearance Discrimination, Employment, and the Law”, Asian American Law Journal, Year: 2007, Volume: 14, (p. 165-204), p. 168; MCCOY, Maura Flaherty, "Classifying Obesity as Disability Under the Americans With Disability Act: How Seff v. Broward County in Incongruent with Recent ADA Litigation”, Catholic University Law Review, Year: 2015, Issue: 64, Volume: 2, (p. 539-562), p. 539.

${ }^{21}$ https://www.crosslandsolicitors.com/site/crossland_news/Employer_survey_obese_candidates_2015_ht $m l$, (date of access 23.7.2020).

22 ILO, International Labour Conference 100th Session Report I(B), Genova, 2011, p. 53. https://www.ilo.org/wcmsp5/groups/public/---ed_norm/--declaration/documents/publication/wcms_166583.pdf, (date of access 19.8.2020).

23 FLINT, Sturart W. / SNOOK, Jereme, "Obesity and Discrimination: The Next Big Issue", International Journal of Discrimination and the Law, Year: 2014, Volume: 14, Issue: 3, (p. 183193), p. 185.

24 SWAMI / WONG / FURNHAM et al., 2008, p. 971.

25 SWAMI / WONG / FURNHAM et al., 2008, p. 977.

26 RHODE, 2009, p. 1037. Victimization and stigmatization also affect people psychologically. Some surveys show that obese individuals are at greater risk for mental health problems. Their depression and anxiety levels are higher than non-obese. DEĞİRMENCİ, Taner / KALKAN OĞUZHANOĞLU, Nalan / SÖZERİ VARMA, Gülfizar et. all., "Psychological Symptoms in Obesity and Related Factors", Arch Neuropsychiatry, Year: 2015, Issue: 52, (p. 42-46), p. 44.

27366 F. Supp. 763 (1973). https://law.justia.com/cases/federal/district-courts/FSupp/366/763/1502562/, (date of access 8.8.2020). 
colleagues. Although gaining weight was a cause for termination of the contract for females, males were not under the same provision. It shows us that women encounter more discriminatory behaviors than men. ${ }^{28}$ In other words, besides the unfair treatment between obese and non-obese employees are seen; the employers may behave differently between obese men and obese women. ${ }^{29}$ A survey also shows us that obese women are likely to face discrimination than obese men, especially applying for a job if the job needs high visibility and physical demands. ${ }^{30}$

This article is organized into three sections. It will be first examined the legal grounds of equality and prohibition of weight discrimination in some legal systems as well as in ILO and EU. Subsequently, weight discrimination will be discussed under Turkish labour law. In this section, it will be examined whether there are any provisions against weight discrimination in terms of Turkish law. Then, an answer to whether obesity is accepted as a disability in Turkish labour law will be sought. Finally, court decisions regarding weight discrimination in recruitment practices and termination of contracts will be examined.

\section{LEGAL BASES OF EQUALITY AND PROHIBITION OF WEIGHT DISCRIMINATION}

\section{A. International Labour Organization}

International Labour Organization (ILO) as a United Nations' specialized tripartite agency sets universal labour standards with its normative functions. While determining international standards, it regulates Conventions, Protocols, and Recommendations. A few of these legal documents are, of course, about equality and anti-discrimination.

28 CORBERTT, William R., "Hotness Discrimination: Appearance Discrimination as a Mirror for Reflecting on the Body of Employment-Discrimination Law", Catholic University Law Review, Year: 2011, Volume: 60, Issue: 3, (p. 615-660), p. 625.

29 SHINALL, Jennifer Bennet, "Distaste or Disability: Evaluating the Legal Framework for Protecting Obese Workers”, Berkeley Journal of Employment and Labour Law, Year: 2006, Volume: 37, Issue: 1, (p. 101-142), p. 103; FLINT / CODREANU / GOMOIU et al., 2015, p. 65.

30 FLINT / CODREANU / GOMOIU et al., 2015, p. 65. 
C111-Discrimination (Employment and Occupation) Convention, 1958 (No. 111), is one of the fundamental Conventions that put the member States under obligation to declare and pursue a national policy eliminating discrimination. ${ }^{31}$ Under article $1 / 1$, a the term of discrimination means: "any distinction, exclusion or preference made on the basis of race, colour, sex, religion, political opinion, national extraction or social origin, which has the effect of nullifying or impairing equality of opportunity or treatment in employment or occupation." At the same time, any distinction, exclusion or preference shall not be considered discrimination in respect of a particular job based on the inherent requirements. As is seen, neither weight nor appearance is arranged as a ground explicitly. However, article 1/1,b allows that the member States may prohibit discrimination based on other grounds. It means that the member States may also regulate provisions that proscribe weight discrimination.

R111-Discrimination (Employment and Occupation) Recommendation, 1958 (No. 111 ) is another regulation about anti-discrimination. The term discrimination is also defined here as in the C111. Hence, neither weight nor appearance is arranged as a ground. Nevertheless, it accepts that any distinction, exclusion or preference based on other grounds is also discrimination.

Another important Convention about weight discrimination is the C158Termination of Employment Convention, 1982 (No. 158). With this Convention, the employer's right to terminate is restricted in some cases. Under article 4, "the employment contract shall not be terminated unless there is a valid reason for such termination connected with the capacity or conduct of the worker or based on the operational requirements of the undertaking, establishment or service." In other words, if the employer decides to terminate the contract, he/she should assert a valid reason provided it is a necessity based on the employee's conduct or performance or operational requirements of the undertaking, establishment or service. Also, in the Convention,

31 In 1998, ILO accepted the Declaration on Fundamental Principles and Rights at Work. With this Declaration, even if the member State has not ratified the core Conventions in question, the State should respect, promote, and realize them in good faith. For the text of the Declaration: https://www.ilo.org/declaration/thedeclaration/textdeclaration/lang--en/index.htm, (date of access 4.9.2020). 
various situations that are not considered valid reasons are counted as examples. For instance, in article 6 , it is regulated that temporary absence from work because of illness is not a valid reason for termination. In this circumstance, weight may not be accepted as a valid reason for termination of the contract.

\section{B. European Union}

Equality is one of the cornerstones in the European Union (EU) law. ${ }^{32} \mathrm{EU}$ is founded on respect for human rights and fundamental freedoms and attachment to the principles of liberty and democracy. From this perspective, to establish the principle of equal treatment and non-discrimination, the EU proclaimed some very effective and significant legal documents. Firstly, the principle of equality and non-discrimination is located in the Treaty on European Union (TEU) ${ }^{33}$. It is accepted in article 2 that the EU is founded on the value of equality, and non-discrimination is a shared value of the Member States. Also, in article 3/3, it is expressed that the internal market, which is established by the EU, combats discrimination and shall promote social justice and protection, equality between women and men.

The other constitutional Treaty forming the EU is the Treaty on the Functioning of the European Union (TFEU) ${ }^{34}$. According to article 8 of TFEU, one of the EU's goals is to eradicate inequalities and promote equality in all activities. Under article 10, the EU should combat discrimination based on "sex, racial or ethnic origin, religion or belief, disability, age or sexual orientation." Also, article 19 allows European Parliament to take appropriate actions to combat discrimination based on "sex, racial or ethnic origin, religion or belief, disability, age or sexual orientation".

32 MCCRUDDEN, Christopher / PRECHAL, Sacha, "The Concepts of Equality and Non-Discrimination in Europe: A Practical Approach", European Commission Directorate-General for Employment, Social Affairs and Equal Opportunities, Unit G. 2, Year: 2009, p. 4.

33 For the Consolidated version of the Treaty on European Union: https://eur-lex.europa.eu/legalcontent/EN/TXT/? uri=CELEX\%3A12012M\%2FTXT, (date of access 5.4.2020).

34 For the Consolidated version of the Treaty on the Functioning of the European Union: https://eurlex.europa.eu/legal-content/EN/TXT/?uri=celex\%3A12012E\%2FTXT, (date of access 5.4.2020). 
Another worth noting document is the Charter of Fundamental Rights of the European Union (Charter). ${ }^{35}$ Article 21 of the Charter prohibits particular types of discrimination. According to the article, "any discrimination based on any ground such as sex, race, colour, ethnic or social origin, genetic features, language, religion or belief, political or any other opinion, membership of a national minority, property, birth, disability, age or sexual orientation shall be prohibited." Although more grounds are counted than in TFEU, weight discrimination is not prohibited explicitly under article 21. However, as stated below, the Court of Justice of the European Union (CJEU) has discussed whether obesity is a disability or not. In this context, Article 26 of the Charter should also be examined. It imposes to the Member States take necessary measures to persons with disabilities. According to the relevant article titled as the integration of persons with disabilities, "The Union recognizes and respects the right of persons with disabilities to benefit from measures designed to ensure their independence, social and occupational integration and participation in the life of the community."

The other important legal document is Council Directive 2000/78/EC. ${ }^{36}$ This Directive combats discrimination on the grounds of "religion or belief, disability, age or sexual orientation." In other words, the Directive purposes to stipulate a general framework for combating discrimination on the grounds of religion or belief, disability, age or sexual orientation relating to employment and occupation. As it is seen, it does not prohibit weight discrimination explicitly. Nevertheless, the CJEU makes a connection between disability and obesity by interpreting the meaning of disability. ${ }^{37}$ In Fag og

35 EUROPEAN AGENCY FOR FUNDAMENTAL RIGHTS, Handbook on European NonDiscrimination Law, 2018, https://fra.europa.eu/sites/default/files/fra_uploads/1510-FRA-CASE$L A W-H A N D B O O K_{-} E N . p d f$, (date of access 2.8.2020), p. 15. For the Charter: https://eurlex.europa.eu/legal-content/EN/TXT/?uri=CELEX:12012P/TXT, (date of access 21.7.2020).

36 https://eur-lex.europa.eu/legal-content/EN/TXT/?uri=celex\%3A32000L0078, (date of access 23.7.2020).

37 After being approved the UN Convention on the Rights of Persons with Disabilities (CRPD) by Council Decision 2010/48/EC, the UN Convention also has become a reference point for interpreting the notion of disability. For accessing the Decision: https:/leur-lex.europa.eu/legalcontent/EN/TXT/? uri=CELEX\%3A32010D0048, (date of access 17.8.2020). International agreements are considered as a source of the Union law. However, they are below the provisions of the Treaties, higher than secondary law. FAVALLI, Silvia / FERRI, Delia, "Tracing the Boundaries Between Disability and Sickness in the European Union: Squaring the Circle", European Journal of Health Law, Year: 2006, Issue: 23, Volume: 1, (p. 5-35), p. 8 and 28. 
Arbejde v Kommunernes Landsforening ${ }^{38}$, Mr. Kaltoft was an employee as a childminder in the Municipality of Billund. For the entire period during his employment, he was an "obese" according to the criteria determined by WHO. When he took leave of one year, the employer fired him because there was no need for his help for the decrease in the number of children who need care. However, he was the only one whose contract was terminated. Subsequently, he brought an action before the Court. He alleged that his contract was terminated because of his obesity. The Court tried to seek an answer to whether there is a prohibition under EU anti-discrimination law on obesity grounds. It is stated that TEU, TFEU or Directive 2000/78 do not explicitly prohibit discrimination on the ground of obesity. However, the Court interpreted obesity as a disability under Directive 2000/78. The significant thing here is that firstly the Court was not interested in the reasons for obesity. Secondly, the Court did not rule that obesity equals to disability. ${ }^{39}$

According to these legal documents and the court decisions, the EU antidiscrimination law prohibits discriminatory behavior in two main ways: direct and indirect discrimination. ${ }^{40}$ Direct discrimination means treating someone less favorably than the others who are in a comparable situation based on protected grounds unless such

38 Case C-354/13. https://eur-lex.europa.eu/legalcontent/EN/TXT/?qid=1490004648277\&uri=CELEX:62013CJ035, (date of access 15.7.2020).

39 See also BOURBON, Alexandra, "Fag og Aberjde (FOA) v. Kommunernes Landsforening (KL): Will Expanding the Definition of Disability to Include Obesity Lead to an Expanding Waistline in Europe", Tulane Journal of International and Comparative Law, Year: 2016, Volume: 24, Issue: 2, (p. 351370), p. 352 ff.; DAMAMME, Joseph, "How Can Obesity Fit within the Legal Concept of Disability A Comparative Analysis of Judicial Interpretations under EU and US Non-Discrimination Law after Kaltoft", European Journal of Legal Studies, Year: 2015, Volume: 8, Number: 1, (p. 147-179), p. 148 $f f$.

40 BAKIRCI, Kadriye, Uluslararası Hukuk, AB ve ABD Hukuku ile Karşılaştırmalı Çalışma Yaşamında Kadın Erkek Eşitliği Arayışı Cinsiyet Ayrımcılığı Yasağı ve Türkiye, Seçkin Yayınevi, İstanbul, 2012, p. $245 \mathrm{ff}$. In Turkish labour law, the notion of direct and indirect discrimination is accepted. For example, according to the Act of Human Rights and Equality Institution of Turkey, Act no. 6701, whereas direct discrimination means that "any different treatment that hinders or makes it difficult for a natural or legal person to enjoy legally recognized rights and freedoms equally compared to those in comparable situations", indirect discrimination means that "putting a natural or legal person into a disadvantageous position that cannot be objectively justified in terms of enjoying legally recognized rights and freedoms, in connection with the grounds of discrimination enumerated in this Act, as a result of all kinds of seemingly non-discriminatory acts, transactions, and practices." For the concept of direct and indirect discrimination in Turkey, see also KARAN, Ulaş, Uluslararası İnsan Hakları Hukuku ve Anayasa Hukuku Işı̆̆ında Eşitlik İlkesi ve Ayrımcılık Yasağı, 12 Levha Yayınevi, İstanbul, 2017, p. 203 vd. 
treatment is objectively justified. ${ }^{41}$ For example, if the employer refuses to recruit an applicant just because he is gay, it is direct discrimination. On the other hand, in some cases, even if policies, rules or practices apply to everyone and look neutral, they may be discriminative against some people. It is called indirect discrimination. For example, the European Court of Justice has recognized the national legislation that excludes certain part-time employees from continuing to pay wages in the event of illness as indirect discrimination. Because this arrangement disproportionately affected women. ${ }^{42}$ In this context, weight can be assessed within the framework of direct and indirect discrimination too.

\section{United States}

The United States has several legal documents that proscribe discrimination in the workplace. However, when the subject comes to weight, there is no anti-discrimination law based on weight at the federal level. ${ }^{43}$ Initially, Title VI of the Civil Rights Act of 1964 (Civil Rights Act) is of importance to all employee-employer relationships, even for job applicants. ${ }^{44}$ According to the Act, if an employer "fails or refuses to hire or to discharge any individuals, or otherwise to discriminate against any individual with respect to his compensation, terms, conditions, or privileges of employment, because of such individual's race, color, religion, sex, or national origin", it is accepted an unlawful

41 For example, in Council Directive 2000/43/EC which is known as Racial Equality Directive, direct discrimination is described as "direct discrimination shall be taken to occur where one person is treated less favourably than another". For the Directive: https:/leur-lex.europa.eu/legalcontent/EN/TXT/? uri=CELEX\%3A32000L0043, (date of access 4.8.2020). Also, in Council Directive 2006/54/EC, The Gender Recast Directive, defines direct discrimination. According to this Directive, direct discrimination is "where one person is treated less favourably on grounds of sex than another is, has been or would be treated in a comparable situation". For the Directive: https://eurlex.europa.eu/legal-content/EN/TXT/? uri=CELEX\%3A32006L0054, (date of access 4.8.2020). See also: TIMMER, Alexandra / SENDEN, Linda, Gender Equality Law in Europe-How are EU Rules Transposed into National Law in 2016, Luxemburg: Publications Office of the European Union, 2016, p. $7 f f$.

42 Case C-171/88, Ingrid Rinner-Kühn v FWW Spezial-Gebäudereinigung GmbH \& Co. KG., also see BAKIRCI, Kadriye, Uluslararası Hukuk, AB ve ABD Hukuku ile Karşılaştırmalı İş Hukukunda Cinsiyet Ayrımcılığı Yasağı İlkesinin İstisnaları ve Objektif Haklı Nedenler, Seçkin Yayınevi, İstanbul, 2012, p. 46.

43 CORBERTT, 2011, p. 624.

44 CAVICO / MUFFLER / MUJTABA, 2011, p. 794. 
employment practice. ${ }^{45}$ Also, limiting, segregating or classifying an employee or applicant because of his/her race, color, religion, sex, or national origin is an unlawful employment practice. ${ }^{46}$ What makes the Act important is that it leads to two theories which Courts use. They are disparate treatment and disparate impact. ${ }^{47}$

If an employer willfully and purposefully treats an employee or applicant less favorably based on race, color, religion, sex or national origin than other employees or applicants, it is disparate treatment. ${ }^{48}$ For example, when a man and woman apply for a job at the same time, if the employer does not hire her because of her sex, this is a disparate treatment based on sex. On the other hand, in disparate impact theory, a particular employment practice looks neutral, the employer does not have discriminatory intent, but his practice has a disparate effect on employees' and applicants' race, color, religion, sex or national origin. ${ }^{49}$ For example, in Griggs v. Duke Power Co. ${ }^{50}$, Duke Power Company employed African Americans in the labour department where wages were low. Except for this department, employees had to have a high school diploma or pass two tests for being employed in other departments. At that time, African Americans had segregation in educational opportunities; most of them could not finish high school or have the same educational skills compared to White Americans. According to these conditions, The Supreme Court decided that there was a disparate effect in there, and the term about educational qualification imposed by the employer was illegal.

As we can see, the Civil Rights Act protects against discrimination based on race, color, religion, sex or national origin, but not weight. It means discrimination based on weight is not illegal, according to the Act. ${ }^{51}$ In other words, there is no legal remedy for

45 Title VI of the Civil Rights Act of 1964, 42 U.S.C. Section 2000-e-2(a) (1).

46 Title VI of the Civil Rights Act of 1964, 42 U.S.C. Section 2000-e-2(a) (2).

47 See also BAKIRCI, 2012 (a), p. 243.

48 See also JOLLY-RYAN, Jennifer, "Have a Job to Get a Job: Disparate Treatment and Disparate Impact of the 'Currently Employed' Requirement", Michigan Journal of Race and Law, Year: 2012, Volume: 12, (p. 189-212). p. 200.

49 MAHAJAN, 2007, p. 178.

50401 U.S. 424 (1971). Also, in BAKIRCI, 2012 (b), p. 43; JOLLY-RYAN, 2012, p. 203.

51 MAHAJAN, 2007, p. 177. 
weight discrimination under the Civil Rights Acts. However, if weight discrimination and the other discriminations mentioned in the Acts occur at the same time, employees and applicants can be protected under the Act. ${ }^{52}$ For example, if the employer does not hire the applicant because she is obese and woman, it will be illegal under the Act.

The Americans with Disabilities Act (ADA) is also of great importance at the federal level. ADA's purposes are to eliminate discrimination against individuals with disabilities and determine clear, strong, consistent, enforceable standards addressing that. For achieving these purposes, the ADA will be applied in all critical areas, including employment relationships. ${ }^{53}$ In other words, discrimination based on disability in employment relations is prohibited by the ADA. No one can discriminate against a qualified individual based on disability in relation to job application procedures, the hiring advancement, applying working conditions or termination of the contract. ${ }^{54}$

What makes the ADA important within our article's scope is the acceptance of weight as a state of disability. ${ }^{55}$ Due to the lack of legal documents that forbid weight discrimination at the federal or state level, most cases concerning weight discrimination have been prosecuted under the ADA. ${ }^{56}$ According to court practices, if someone claims that he/she faced discrimination because of his/her disability due to the weight, the three questions must be answered affirmatively. ${ }^{57}$ The first question is: "Is there a disability within the meaning of the ADA?". According to the ADA, the term disability means that "a physical or mental impairment that substantially limits one or more major life activities of such individual" or "a record of such an impairment" or "being regarded as

52 HUGGINS, 2015, p. 906.

53 Title I of the ADA covers employment relationships.

54 According to the Sec. 12112. (a) titled as general rule for discrimination, it is stated that "No covered entity shall discriminate against a qualified individual on the basis of disability in regard to job application procedures, the hiring, advancement, or discharge of employees, employee compensation, job training, and other terms, conditions, and privileges of employment."

55 MCCOY, 2015, p. 541.

56 PUHL / DEPIERRE, 2012, p. 32; HUGGINS, 2015, p. 909.

57 See Hamilton v. Sw. Bell Tel. Co., 136 F.3d 1047, 1050 (5th Cir.1998); EEOC v. Resources for Human Development, Inc., 827 F. Supp. 2d 688 (E.D. La. 2011).; US District Court for the Southern District of Texas - 923 F. Supp. 965 (S.D. Tex. 1996). 
having such an impairment." ${ }^{, 58}$ For example, if obesity obstructs activities such as walking, breathing, working, it may be accepted as a disability under the ADA.

The second question is: "Is the complaining party a qualified individual with a disability?". In the ADA, the qualified individual has been identified as "an individual who, with or without reasonable accommodation, can perform the essential functions of the employment position that such individual holds or desires." 59 For example, if the employee uses the computer at work without any trouble, he/she may be accepted as a qualified individual.

The third question is: "Did the complaining party suffer an adverse employment decision because of the disability?". It means that the employer's decisions must be evaluated under the disparate treatment and disparate impact theories. For example, if the employer terminates the contract only on the grounds of disability, it can be accepted that the employee suffers an adverse employment decision. ${ }^{60}$ If the three questions does not meet simultaneously, obesity cannot be seen as an impairment under the ADA. In other words, obesity, morbid obesity or emaciation alone does not qualify as a covered disability under the ADA. On the contrary, if the applicant or employee is discriminated against under the ADA, which also means employee who successfully files disability discrimination claims, there are several remedies existing. ${ }^{61}$

There are also some legal remedies against weight discrimination in the USA. Some States like Michigan, Maryland, New York, Illinois, Wisconsin, and California, and the Washington DC have a direct or indirect remedy for weight or appearance

58 Sec. 12102. (1).

59 Sec. 12111. (8).

60 Depending on the answers, if the Court accepts the plaintiff has a disability, The Court seeks whether the employers are required to provide reasonable accommodations for her/him. If the employers did not provide reasonable accommodation, The Court rules that there is a disability discrimination in that case.

61 For the remedies see. http://www.southwestada.org/html/publications/ebulletins/legal/2010/june2010.pdf, date of access 6.4.2020); DOELLMAN, David A., "Statutory Leapfrog: Compensatory and Punitive Damages under the Retaliatory Provision of the ADA", Missouri Law Review, Year: 2009, Volume: 74, Issue: 1, (p. 173-191). 
discrimination. ${ }^{62}$ For example, though Michigan has direct legislation, Washington DC indirectly prohibits weight discrimination. In Michigan, the Elliott-Larsen Civil Rights Act (Act 453 of 1976) prohibits discriminatory practices based upon "religion, race, color, national origin, age, sex, height, weight, familial status, or marital status" in hiring or recruiting, discharging or in any case discriminating against an individual concerning employment, compensation or a term, condition or privilege of employment. ${ }^{63}$ In Washington DC, obesity is not addressed explicitly, but discrimination based on personal appearance is proscribed in employment practices such as hiring, recruiting, discharging. ${ }^{64}$

\section{United Kingdom}

The main legal document which protects people in the workplace against discrimination in the United Kingdom (UK) is The Equal Act 2010. In the Act, some characteristics such as "age, disability, gender reassignment, marriage and civil partnership, pregnancy and maternity race, religion or belief, sex, and sexual orientation" are accepted as protected characteristics. ${ }^{65}$ However, weight is not explicitly regulated in this Act. Therefore, weight discrimination must comply with one of the characteristics specified in the Act to be covered by the law. In this framework, it has been discussed whether obesity is a disability.

The notion of disability is arranged in Section $6 .{ }^{66}$ According to this, disability means physical or mental impairment which has a substantial and long-term adverse effect on a person's ability to carry out normal day-to-day activities. Within this context,

62 SHINALL, 2016, p. 103; CORBERT, 2011, p. 624; BIERMAN, 1990, p. 960; HUGGINS, 2015, p. 913; DAMAMME, 2015, p. 157.

63 37.2202. Sec. 202.2 See Act: https://www.michigan.gov/documents/act_453_elliott_larsen_8772_7.pdf, (date of access 7.8.2020).

64 Code of the District of Columbia, Chapter 14, Subchapter II, 2-1402.11.(1). For the Code: https://code.dccouncil.us/dc/council/code/titles/2/chapters/14/, (date of access 7.8.2020). Personal appearance is also described in the Code. According to the 2-1401.01.(22) of the Code, personal appearance means "the outward appearance of any person, irrespective of sex, with regard to bodily condition or characteristics, manner or style of dress, and manner or style of personal grooming, including, but not limited to, hair style and beards."

65 The Equality Act, Part 2, Chapter 1, Section 4.

66 The Equality Act, Part 2, Chapter 1, Section 6. 
if a person's obesity as a physical or mental impairment has a significant and long-term adverse effect on their ability to perform routine daily activities, that person may be considered disabled. ${ }^{67}$

\section{E. Turkey}

With the establishment of the employment relationship, the employment contract parties fall under various rights and duties. One of the primary duties of the employer is equal treatment. ${ }^{68}$ The pillars of the principle of equal treatment and prohibition of discrimination, especially the prohibition of weight discrimination, find their place in the Constitution of the Republic of Turkey (Constitution) ${ }^{69}$, Turkish Labour Act, No. 4857 $(\mathrm{TLA}))^{70},{ }^{71}$ and also in Act of Human Rights and Equality Institution of Turkey, Act no. 6701 (AHREIT) ${ }^{72} \cdot{ }^{73}$

Initially, article 10 of the Constitution is about equality before the law. According to the article, "all individuals are equal without any discrimination before the law, irrespective of language, race, color, sex, political opinion, philosophical belief, religion and sect, or any such considerations." Also, "men and women have equal rights. The State has the obligation to ensure that this equality exists in practice". ${ }^{74}$ Moreover,

67 FLINT / SNOOK, 2014, p. 187.

68 EKMEKÇİ, Ömer / KORKUSUZ, Refik, Turkish Individual Labour Law, 12 Levha Yayıncılık, İstanbul, 2020, p. 72; SÜZEK, Sarper, İş Hukuku, Beta Yayınevi, İstanbul, 2020, p. 452.

69 Date of Adaption: 7.11.1982, Date of Publication in the Official Journal: 9.11.1982.

70 Date of Adaption: 22.5.2003, Date of Publication in the Official Journal: 10.6.2003.

71 DOĞAN YENİSEY, Kübra, “İş Kanununda Eşitlik İlkesi ve Ayırımcılık Yasağı”, Çalışma ve Toplum Dergisi, Year: 2006, Issue: 4, (p. 63-82), p. 64; KANDEMİR, Murat / YARDIMCIOĞLU, Didem, "İş Hukukunda Eşitlik İlkesi”, Journal of the Faculty of Law Dicle University, Year: 2014, Volume: 19, Issue: 30-31, (p. 1-44), p. 6 ff.

72 Date of Adaption: 6.4.2016, Date of Publication in the Official Journal: 20.4.2016.

73 SENYEN KAPLAN, Emine Tuncay, “İş Hukukunda Eşitlik İlkesi ve Cinsiyet Ayrımı”, Türkiye Barolar Birliği Dergisi, Year: 2017, Special Issue, (p. 225-268), s. 237 ff.; ÇELİK, Nuri / CANIKLİĞGLU, Nurşen / CANBOLAT, Talat, İş Hukuku Dersleri, Beta Yayınevi, İstanbul, 2019, p. 414; GÜVEN, Ercan / AYDIN, Ufuk, Bireysel İş Hukuku, Nisan Kitapevi, Eskişehir, 2020, p. 236; EKMEKÇİ, Ömer / YİĞİT, Esra, Bireysel İş Hukuku Dersleri, 12 Levha Yayıncılık, İstanbul, 2020, p. 276.

74 In paragraph 2, it is also arranged that "The State has the obligation to ensure that this equality exists in practice. Measures taken for this purpose shall not be interpreted as contrary to the principle of equality.". 
paragraph 3 regulates that the measures to be taken for the disabled persons shall not be considered a violation of the principle of equality. ${ }^{75}$

Article 11 is also noteworthy. Under the article, the Constitution's provisions are fundamental legal rules, and these rules are binding upon the legislative, executive, judicial organs, administrative authorities, and other institutions and individuals. Since the prohibition of discrimination is a fundamental legal rule, article 10 also binds the parties of employment relations.

The other legal document that has provisions about equality, also the prohibition of discrimination is TLA. Article 5 of the TLA is titled the principle of equal treatment. According to paragraph 1 of article 5, "no discrimination based on language, race, color, sex, disability, political opinion, philosophical belief, religion and sect or similar reasons is permissible in the employment relationship". Although the article's title is equal treatment, it is difficult to say that it regulates the principle of equality. Because, according to paragraph 2, unless there are substantial reasons, it is prohibited any discrimination between types of contracts (full time-part time or contract of the definiteindefinite term). Also, under paragraph 3, "Except for biological reasons or reasons related to the nature of the job, the employer must not make any discrimination, either directly or indirectly, against an employee in the conclusion, conditions, execution, and termination of her/his employment contract due to the employee's sex or maternity." In this framework, article 5 regulates the prohibition of discrimination. ${ }^{76}$

The provisions about termination are regulated between article 17-25 of the TLA. The regulations limiting the employer's right to terminate are stipulated in these articles. In Turkish labour law, one of the main differences is made between employees covered by employment security and employees not covered by employment security. ${ }^{77}$

75 Constitution of Republic of Turkey, article 10, paragraph 3 is: "Measures to be taken for children, the elderly, disabled people, widows and orphans of martyrs as well as for the invalid and veterans shall not be considered as violation of the principle of equality."

76 SUR, Melda, "İş İlişkisinde Eşitlik İlkesi ve Ayrımcılık Yasağı", Sicil İş Hukuku Dergisi, Year: 2017, Issue: 37, (p. 33-51), p. 36; SÜZEK, 2020, p. 453.

77 An employee must meet certain conditions to be considered within the scope of employment security. According to article 18 of the TLA, the employee must work under an indefinite contract in an establishment that runs at least 30 employees and must have seniority of at least six months. Also, the 
According to article 18, if the employer wants to terminate the contract of an employee covered by employment security, he/she must depend on a valid reason for such termination connected with the capacity or conduct of the employee or the operational requirements of the undertaking, establishment or service. Therefore, it should be considered whether weight is a valid reason.

Termination of the contract of the employment with just cause is arranged in article 24 (for employees) and article 25 (for employers). In article 25, just causes have been grouped under four headings which are "health reasons", "immoral or malicious conduct or other similar behavior", "force majeure", and "being taken into custody or being arrested". In these circumstances, it should be examined whether the employee's weight can be considered a just cause if it fits one of the headings.

Another basis of the principle of equal treatment is mentioned in the AHREIT. Firstly, according to article 3/1, everyone is equal in the enjoyment of legally recognized rights and freedoms, which means all parties of the employment contract are considered under this Act. Subsequently, according to article 6/1, employers are prohibited from discriminating in each of the processes related to recruitment, execution, and termination of the contract. ${ }^{78}$ Moreover, according to article 6/5, not only employment relations but also all kinds of works and services fall within the scope of the Act. In other words, the Act can be applied to independent contractors, civil servants and employees. ${ }^{79}$ These articles show us that TLA and AHREIT complement each other and cannot be thought of separately.

employee should not be the employer's representative and his/her assistants who are authorized to manage the entire establishment, or he/she should not be the employer's representative who is authorized to manage the entire workplace and to recruit and dismiss employees. For the conditions to be considered within the scope of employment security in Turkish labour law see. CENTEL, Tankut, İş Güvencesi, Legal Yayınevi, İstanbul, 2020, p. 33-66.

78 ODYAKMAZ, Zehra / KESKIN, Bayram / DENIZ, Yusuf, "6701 Sayılı Türkiye İnsan Hakları ve Eşitlik Kurumu Kanunu Üzerine Bir Değerlendirme- I”, Uyuşmazlık Mahkemesi Dergisi, Year: 2016, Issue: 71, (p. 721-761). p. 750.

79 BAKIRCI, Kadriye, "Eşitlik Kurulu Kanunu ile Anayasa ve İş Kanunu'nun İlgili Hükümleri Üzerine Bir Değerlendirme”, Emeğin Hukuku Kurultayı 2, Türkiye Barolar Birliği Yayını, Ankara, Year: 2017, (p. 65-75). p. 72 and 73. 
Article 3 of this Act is titled equal treatment and prohibition of discrimination. With this article, discrimination based on "sex, color, language, religion, sect, philosophical belief, political opinion, ethnic origin, property, birth, marital status, health status, disability and age" is prohibited. ${ }^{80}$ The point that needs attention in terms of our article is in here that even though discrimination on the basis of disability is prohibited, weight discrimination is not proscribed. Besides, in connection with discrimination, the situations in which the discrimination claim cannot be put forward are also arranged in article 7. Lastly, one of the most significant remedy, which is stipulated in article 17 , brought by the Act is individuals who are damaged from the violation of the prohibition of discrimination can apply to the Human Rights and Equality Institution. After the application, the Institution can conduct an administrative investigation against those who act against the prohibition.

\section{WEIGHT DISCRIMINATION IN TURKISH LABOUR LAW}

Weight discrimination can be considered in three different situations: recruitment, execution of the contract and termination. Primarily, it is accepted in recruitment that employers are free to choose with whom to work. ${ }^{81}$ But, the employer's freedom is limited to comply with the principle of the prohibition of discrimination, which is regulated explicitly in the legislation. It should be stated that weight discrimination is not often visible. Employers allege various reasons instead of apparently stating the reasons why they do not hire obese applicants, such as not having an adequate background, disagreement about wages, etc. Obesity is scarcely shown as a direct cause for not hiring. Additionally, when considering article 5 of the TLA, the prohibition of discrimination begins after the employee-employer relationship is established. ${ }^{82}$ Only discrimination

80 The adaption of the principle of numerus clausus has been criticized by commentators. In their view, I also agree with, this regulation should have been open-ended, the same as in article 5 of the TLA. See. SUR, 2017, p. 37.

81 KESER, Hakan, "4857 Sayı1ı İK'na Göre İşverenin İş Sözleşmesi Yapma ve İş İlişkilerinde Eşit İşlem Yapma Yükümlülükleri ve Bunlara Aykırı Davranması Durumunda Karşılaşacağı Yaptırımlar", Kamu İş Dergisi, Year: 2004, Volume: 7, Issue: 3, (p. 1-38), p. 2 ff.; SÜZEK, 2020, p. 459; GÜVEN / AYDIN, 2020, p. 236.

82 EKMEKÇİ / YİĞİT, 2020, p. 276. 
based on maternity and sex is proscribed in recruitment. In this circumstance, an applicant who faced weight discrimination cannot enjoy article 5. Furthermore, he/she cannot be considered within the scope of AHREIT, because weight discrimination is not prohibited explicitly in this Act. However, the applicant can consult the general provisions within the scope of the law of obligations. ${ }^{83}$

The duty of equal treatment and non-discrimination of the employer mainly arises during the execution of the contract. Once the employment relationship is established, parties fall under the provisions of article 5 of the TLA. When we analyze article 5, discrimination based on some grounds such as race, color, sex, disability is proscribed, furthermore the expression of "and similar reasons" is stated ${ }^{84}$ For example, it is accepted that discrimination based on age, sexual orientation or genetic data is also prohibited. ${ }^{85}$ Within this framework, it should be evaluated whether weight can be considered in "similar situations". The primary purpose of article 5 is to ensure equality among employees based on justice and equity, ensure work peace by prohibiting different treatment between employees alike, and prevent employees from being subjected to different treatment without objective or subjective reasons. ${ }^{86}$ From this perspective, weight cannot be a reason for a different treatment, unless there is an objective or a subjective reason. ${ }^{87}$ Hence, in my opinion, weight should be evaluated under the "similar reason".

83 SÜZEK, 2020, p. 460; SUR, 2017, p. 41.

84 It is also called "open system". There are two systems what might be called closed and open system. In the open system, various grounds are listed but left open ended. But contrary to this, in closed system, listed grounds are the only grounds, and courts cannot increase the type of grounds (the principle of numerus clausus). MCCRUDDEN / PRECHAL, 2009, p. 3; DAMAMME, 2015, p. 154.

85 TAŞDEMIR, Yasemin, "İş Hukukunda Genetik Ayrımcıllk Yasağı”, Dokuz Eylül Üniversitesi Hukuk Fakültesi Dergisi, Year: 2020, Issue:22, Volume: 2, (p. 947-990). p. 973; ÜNAL, Canan, İş Hukukunda Yaş Ayrımcılı̆̆, 12 Levha Yayıncılık, İstanbul, 2018, p. 291; ÇELİK / CANIKOĞLU / CANBOLAT, 2019, p. 415; SENYEN KAPLAN, 2017, p. 236. Also, in the AHREIT, it is explicitly accepted that discrimination based on wealth, birth, marital status, health status, disability and age is prohibited (Article 3). "... Since the provision includes the notion "and similar reasons", the prohibition of discrimination is not limited to the aforementioned grounds, the employer will not be able to violate the discrimination prohibition for similar reasons ..." Court of Cassation, General Assembly, 25.2.2020, 370/201.

86 See. Court of Cassation, $9^{\text {th }}$ Civil Chamber, 14.12.2020, 34591/18303; Court of Cassation, $9^{\text {th }}$ Civil Chamber, 9.12.2020, 34268/17873.

87 SENYEN KAPLAN, Emine Tuncay, Bireysel İş Hukuku, Gazi Kitapevi, Ankara, 2019, p. 242. 
The consequence of interpreting the weight as one of the prohibited grounds manifests itself in the claim for the discrimination compensation. According to paragraph 6 of article 5, the employee may demand compensation up to his/her four months' wages if the employer violates the provision, which proscribes weight discrimination stipulated in paragraph 1. Also, the employee may demand other claims of which he/she has been deprived.

It is still controversial whether employers are subject to the provisions of equal treatment in the termination of the contract. One view, with which I also agree, has expressed that there may not be said that employers have a duty of equal treatment in the course of termination. Nevertheless, they have to comply with the prohibition of abuse of the right to termination. ${ }^{88}$ Except for the abuse of the right of termination, employers can terminate the contract whenever they want. ${ }^{89}$ As mentioned above, in Turkish labour law, employees covered by employment security and employees not covered by employment security are subject to separate provisions. For the employees not covered by employment security, the prohibition of the abuse of the right of termination is the only hindrance for the employer to terminate the contract whenever he/she wants. ${ }^{90}$ In this framework, without any valid reason, termination of the contract based on weight solely is an abuse of the right. In this context, although the employee cannot return to the job, he/she may demand compensation three times the notice period according to article $17 / 6 .^{91}$

For termination of the contract of the employee covered by employment security, the employer needs a valid reason connected with the employee's capacity or conduct, or

88 TUNÇOMAĞ, Kenan / CENTEL, Tankut, İş Hukukunun Esasları, Beta Yayınevi, İstanbul, 2018, p. 146; ÇELIK / CANIKOĞLU / CANBOLAT, 2019, p. 420; GÜVEN / AYDIN, 2020, p. 239; SENYENKAPLAN, 2019, p. 243; SÜZEK, 2020, p. 543.

89 On the other hand, the other view claims that employers have duty of equal treatment in the termination of the contract. See in BAŞBUĞ, Aydın / YÜCEL BODUR, Mehtap, İş Hukuku, Beta Yayınevi, İstanbul, 2018, p. 156; SUR, 2017, p. 41.

90 SÜZEK, 2020, p. 543.

91 This compensation is known as "malevolence compensation" in the Turkish labour law. It should also be mentioned that, within the scope of Article 5, although the employee has the right to claim discrimination compensation, it has been stated that both compensations cannot be demanded at the same time. Because discrimination is a special form of malevolence. SÜZEK, 2020, p. 474. 
operational requirements of the undertaking, establishment or service. ${ }^{92}$ In article 18 , it is arranged that some situations shall not constitute a valid reason for termination. According to article 18/3-d," race, color, sex, marital status, family responsibilities, pregnancy, religion, political opinion, and similar reasons" are not valid reasons for termination. Based on this, weight should be evaluated within the framework of similar situations. In other words, weight does not constitute a valid reason for termination. On the other hand, weight can be assessed within the employee's capacity or conduct according to the concrete case. What counts here is that all employees should be evaluated individually, and this is essential in employment security; because weight affects each one differently. ${ }^{93}$ For example, working less efficiently than the other employees, getting sick frequently, an illness that negatively affects performance can be seen as a valid reason connected with the employee's capacity. ${ }^{94}$ Moreover, as mentioned above, operational requirements of the undertaking, establishment or service can be valid reason. For example, if the mannequin, who works as face of a brand of a company which produces clothes for zero-size people, will no longer present these clothes due to the weight he/she gains, it should be accepted that there may be a valid reason in here. ${ }^{95}$

Finally, if the court rules that there is an invalid termination of the contract of the employee covered employment security, the employee may request his/her reinstatement. According to article 21, if the court (or a special arbitrator) concludes that the termination is unjustified because no valid reason has been given or the alleged reason is invalid, the employee can apply to the employer for reinstatement. If the employer reinstates the employee upon the application of reinstatement, the employee can claim compensation up to four months' wage. Besides, the employee may demand discrimination

92 EKMEKÇI / KORKUSUZ, 2020, p. 109.

93 For a similar opinion on age-related see. ÜNAL, 2018, p. 336.

94 ÇELIK / CANIKOĞLU / CANBOLAT, 2019, p. 510; SÜZEK, 2020, p. 573 vd.

95 In this situation, I also emphasize that the employer does not violate the prohibition of discrimination based on weight. Because, to be able to say that weight discrimination occurs, it is necessary to be subjected to different treatment without any objective and subjective reason. In this example, the employer has a reason for the termination. 
compensation up to his/her four months' wages within the scope of article $5 .{ }^{96}$ On the contrary, if the employer does not reinstate him/her, the employee may demand not only compensation up to his/her four months' wages but also employment security compensation. This compensation is determined in the amount of four to eight months' wages of the employee. In this point, there are different opinions about whether discrimination compensation can be claimed in addition to employment security compensation. According to the one view, which also the Court of Cassation agreed with, the employee cannot demand both compensations at the same time. ${ }^{97}$ Because the employer should not be subject to more than one sanction for the same behavior. ${ }^{98}$ Also, on the other hand, the regulation and the prescribed sanctions in article 21 of the TLA include invalid terminations based on malice or discrimination. In other words, in article 21 , the same sanctions are foreseen for all invalidity cases. ${ }^{99}$ According to the opposite opinion, with which I agree, the employee should be able to claim both compensations at the same time. ${ }^{100}$ Because employment security compensation is a sanction for not reinstating the employee. On the other hand, discrimination compensation is the result of the employer's discriminatory behavior. In sum, the employee may demand both at the same time.

It should be examined whether weight can be a just cause for termination. As mentioned above, just causes for the employer are regulated in article 25. Under article

96 Because while up to four months' wage is a sanction for the time without working, discrimination compensation is the sanction of discriminatory behavior. These two compensations have a different purpose, so it should be able to be claimed at the same time.

97 Court of Cassation, $9^{\text {th }}$ Civil Chamber, 6.6.2007, 30630/18174. For the decision review see. TUNCAY, A. Can, "Birden Fazla Tazminat Kapsamına Giren Eylemde Hangi Tazminata Hükmedilecektir?", Sicil İş Hukuku Dergisi, Year: 2008, Volume: 10, (p. 105-110). p. $105 \mathrm{ff}$.

98 TUNCAY, 2008, p. 108.

99 BAKIRCI, Kadriye, "İş Güvencesi Kapsamındaki İşçilerin Doğrudan Tazminat Talep Hakları ve Kötüniyet veya Sendikal Tazminat ile Ayrımcılık Tazminatı İlişkisi”, Sicil İş Hukuku Dergisi, Year: 2006, Volume: 2, (p. 114-121). p. 117.

100 ODAMAN, Serkan, “Ayrımcılık Tazminatının Diğer Tazminatlarla Birlikte Mevcudiyeti Sorunu Üzerine Görüșler”, Sicil İș Hukuku Dergisi, Year: 2009, Volume: 14, (p. 77-83), p. 82; KARAGÖZ, Veli, "İş Hukukunda Ayrımcılık Tazminatı", Erzincan Üniversitesi Sosyal Bilimler Enstitüsü Dergisi, Year: 2012, Volume: 1, (p. 57-76), p. 72; DOĞAN, Gülmelahat, "Ayrımcılık Tazminat1Sendikal Tazminat (Dayandıkları Esaslar ve Farklılıkları)", Ankara Bar Review, Year: 2014, Issue: 1, (p. 361-390), p. 372. 
25 , it is not stipulated that weight can be a just cause, which means that the employer cannot terminate the contract just only due to the weight. However, weight can be assessed under four headings. For example, if the obese employee has contracted a disease owing to his/her deliberate act and as a result of it, the absences have passed for three successive days or more than five working days in any month; it may be accepted as a just cause.

\section{CAN OBESITY BE CONSIDERED AS A DISABILITY IN TURKISH}

\section{LABOUR LAW?}

In the context of legal documents and court decisions mentioned in this article, the question of "Can obesity be considered as a disability in Turkish labour law?" is arising. Before seeking an answer to this question, the meaning of disability should be answered according to Turkish legal documents. There is no definition of disability in the TLA. However, the first Act which indirectly defines disability is the Act on Disabled Persons, No. $5378(\mathrm{ADP})^{101}$. In this Act, the notion of disability is not defined but "disabled person". According to article 3, disabled person means: "person who has difficulties in adapting to the social life and in meeting daily needs due to the loss of physical, mental, psychological, sensory and social capabilities at a various level by birth or by any reason thereafter, and who therefore need protection, care, rehabilitation, consultancy, and support services." ${ }^{" 102}$ However, this article was amended in $2014 .{ }^{103}$ After the amendment, the definition of disabled person became "persons who are affected by attitudes and environmental conditions that restrict their full and effective participation in society under equal conditions with other individuals due to the various loss of physical, mental, spiritual and sensory abilities." Likewise, a similar definition is seen in article 2 of AHREIT.

101 Date of Adaption: 1.7.2005, Date of Publication in the Official Journal: 7.7.2005.

102 This definition has been criticized for creating a pre-acceptance that every disabled person is dependent and need rehabilitation. See. ÜNAL, Canan, "Engellilik Kavramının ve Engellilerin Sosyal Güvenlik Haklarının Uluslararası ve Karşılaştırmalı Hukuk Işı̆̆ında Değerlendirilmesi”, MÜHF Engelli Hakları Komisyonu Engelli Hukukuna Giriş Sempozyumu, Legal Yayıncılık, İstanbul, 2015, p. 36.

103 Date of Acceptance: 6.2.2014; Date of Official Gazette: 19.2.2014. 
According to the definition in article 3 of ADP and article 2 of AHREIT, for determining an obese individual as disabled, some conditions should be fulfilled. Initially, he/she should have a loss of physical, mental, psychological, sensory, and social capabilities. In this context, it does not matter whether this loss is congenital or later. Secondly, the loss of physical, mental, psychological, sensory, and social capabilities should be caused by weight. Thirdly, the loss of physical, mental, psychological, sensory, and social capabilities because of weight should restrict the person fully and effectively participation in society. Finally, this restriction should stem from environmental conditions or the attitudes of other individuals. If these conditions are met, that obese individual can be considered as disabled. For example, suppose an employee who has anorexia nervosa, which is a phycological disorder, experiences a loss of performing daily activities such as the inability to climb stairs or unable to walk. In that case, he/she may be considered disabled. To give another example, a morbidly obese employee has a loss of physical capacities such as driving or walking, and if this loss of physical capacities affects daily routine, the morbidly obese employee may be considered disabled. It is important to remember that not all obesity causes disability. What needs to be noted here is whether obesity prevents a person from participating in life equally when compared to other employees. ${ }^{104}$ If our answer is affirmative, in other words, if the obese employee cannot fully participate in life compared to the others, that employee will be considered disabled.

There are some consequences of the obese individual being considered disabled. First of all, after being accepted as disabled, he/she falls within the scope of the provisions regarding the disability regulated in the TLA or other legal documents. ${ }^{105}$ For example, under article 30, the employer is obliged to employ disabled individuals compatible with their professional skills, physical and mental capacities. Secondly, in AHREIT, it is arranged that not providing reasonable accommodation is another type of discrimination.

104 ÜNAL, 2015, p. 30.

105 If someone is considered as disabled, provisions against disability discrimination show itself from here on. For the prohibition of disability discrimination in Turkish labour law, see. YILDIZ, Gaye Burcu, “Türk İş Hukukunda Özürlülük ve Sağlık Durumuna Dayalı Ayrımcılık Yasağı”, Sicil İş Hukuku Dergisi, Year: 2008, Issue: 10, (p. 80-88). 
According to article 2/1-I and 4, employers are required to take measured, necessary, and appropriate changes for the disabled unless these measures impose a financial burden. For instance, if a morbidly obese employee uses a wheelchair due to his/her weight, the employer should construct a ramp to the entrance of the workplace, if it does not impose a financial burden on the employer. On the contrary, not constructing a ramp can be accepted as discrimination.

\section{WEIGHT DISCRIMINATION IN THE LIGHT OF COURT DECISIONS}

\section{A. In Recruitment}

Weight is one of the factors which influences the employer's perception of the employee. As mentioned above, obese and emaciated applicants are less likely to be hired than normal-weight applicants. ${ }^{106}$ Therefore, some applicants filed complaints claiming that the reason for not being hired was their weight. The first federal court decision I want to examine which held obesity as a disability is the Washington Supreme Court decreed that obesity is an impairment according to the Washington Law Against Discrimination (WLAD). In Taylor v. Burlington Northern Railroad Holdings, Inc. ${ }^{107}$, the plaintiff was an electronic technician, and he received an offer from the employer. ${ }^{108}$ Before hiring, the employer offered a physical and medical examination. According to this examination, he was found morbidly obese. After this result, the employer offered to reconsider if he paid for "expensive" testing. But he could not because it was unaffordable for him. Subsequently, he sued the employer on the grounds of violation of WLAD. He alleged that he was refused because of his "perceived disability". ${ }^{109}$ At the end of the trial, the

106 SWAMI / WONG / FURNHAM et al., 2008, p. 977.

107 Case No. 96335-5. https://caselaw.findlaw.com/wa-supreme-court/1906436.html, (date of access 17.7.2020).

108 Also see (2020). Disability law obesity Washington Supreme Court holds obesity is an impairmentTaylor v. Burlington Northern Railroad Holdings, Inc., 444 P.3d 606 (wash. 2019). Harvard Law Review, Volume: 133, Issue: 5, 1798-1805.

109 The notion of disability under the WLAD is defined as " a sensory, mental, or physical impairment that: is medically cognizable or diagnosable; or exists as a record or history; or is perceived to exist whether or not it exists in fact." 
Supreme Court concluded obesity as a disability, which means the employer discriminated based on disability. ${ }^{110}$

Another decision from USA about weight discrimination in recruitment is Cook $v$. Rhode Island, Department of Mental Health, Retardation, and Hospitals ${ }^{111}$. In that case, the applicant voluntarily worked in a residential facility for mentally disabled persons at the beginning. Then, she applied for working in the same position. According to her prework health examination, she was founded morbidly obese. However, when she was working as a volunteer, her obesity did not affect her ability to do her job. Nevertheless, the employer did not hire her and alleged that her obesity "compromised her ability to evacuate patients in case of an emergency and put her at greater risk of developing serious ailments". After that, she filed a lawsuit alleging weight discrimination. As a result of the trial, the plaintiff was vindicated. The Court accepted obesity as a disability in the sense of the Rehabilitation Act. ${ }^{112}$

The other example of weight discrimination in recruiting practices is the case of EEOC v. Texas Bus Lines. ${ }^{113}$ In that case, the plaintiff applied for a job as a bus driver. Although she passed the driving test successfully, she was found disqualified in her

110 Also see (2020). Disability law obesity Washington Supreme Court holds obesity is an impairmentTaylor v. Burlington Northern Railroad Holdings, Inc., 444 P.3d 606 (wash. 2019). Harvard Law Review, Volume: 133, Issue: 5, 1798-1805. The Court stated that “... obesity is a disability for purposes of the WLAD when (a) the plaintiff's obesity is medically cognizable, medically diagnosable, exists as a record or history, or is perceived to exist whether or not it actually does and (b) the plaintiff's obesity impairs one or more body systems listed in RCW 49.60.040(7)(c)(i). The majority's answer to the certified questions, that obesity is always an impairment for purposes of the WLAD, ignores the need for an individualized inquiry." Case No. 96335-5, para. 47.

11163 Empl. Prac. Dec. P 42,673, 62 USLW, 2345, 2 A.D. Cases 1476, 3 ADD 457, 4 NDLR P 267. https://openjurist.org/10/f3d/17/cook-v-state-of-rhode-island-department-of-mental-healthretardation-and-hospitals, (date of access 20.8.2020).

112 "... We need go no further. In a society that all too often confuses "slim" with "beautiful" or "good," morbid obesity can present formidable barriers to employment. Where, as here, the barriers transgress federal law, those who erect and seek to preserve them must suffer the consequences. In this case, the evidence adduced at trial amply supports the jury's determination that MHRH violated section 504 of the Rehabilitation Act. And because MHRH refused to hire plaintiff due solely to her morbid obesity, there is no cause to disturb either the damage award or the equitable relief granted by the district court." 63 Empl. Prac. Dec. P 42,673, 62 USLW, 2345, 2 A.D. Cases 1476, 3 ADD 457, 4 NDLR P 267, para. 39.

113 US District Court for the Southern District of Texas - 923 F. Supp. 965 (S.D. Tex. 1996). https://law.justia.com/cases/federal/district-courts/FSupp/923/965/1947148/, (date of access 11.9.2020). 
physical examination. According to a report about her, she "would not be able to move swiftly in the event of an accident" because of her morbid obesity. The employer did not hire her based on this report. Subsequently, the Equal Employment Opportunity Commission (EEOC) filed a suit on behalf of her alleged that she faced disability discrimination. Later, the Court was examined that whether she was disabled under the ADA provisions. The Court founded that she was regarded as disabled and the refusal to hire the employee was not job-related, not based on a business necessity and was not justified by health and safety concerns. ${ }^{114}$

The other decision that addresses whether weight discrimination has been made in the workplace is the Div. of Human Rights v. Xerox ${ }^{115}$. In that case, Mrs. McDermott was a computer programmer. She applied for a job at Xerox Corporation. The employer provided a medical examination before employment. According to the examination, the doctor noted in her medical form that she was obese (her weight was about $113 \mathrm{~kg}$ ). Based on her weight solely, she was not accepted for the job. Afterward, she filed a complaint with the State Division of Human Rights charged the employer with a discriminatory employment practice. At the hearing, she stated that her weight did not restrain her from performing any task or function. The Court discussed whether her obesity was a disability under the meaning of the term disability. According to the Court, a disability could manifest itself in two ways: "by preventing the exercise of a normal bodily function" and "by being demonstrable by medically accepted clinical or laboratory diagnostic techniques". In this context, because she was able to work, weight discrimination was not

\footnotetext{
114 “... In the instant case, Dr. Frierson's opinion regarding Manuel's mobility constitutes the same type of direct evidence that Texas Bus Lines regarded Manuel as disabled. Given that evidence of discrimination along with the fact that the health and safety concerns now expressed by Texas Bus Lines are theoretical at best, the Court concludes that Texas Bus Lines has not met its burden of proof on its defense. As none of Texas Bus Lines' claimed defenses is applicable to the uncontested facts of this case, the Court finds that Texas Bus Lines impermissibly discriminated against Arazella Manuel on the basis of a perceived disability in violation of 42 U.S.C. $\$ 12101$ et seq." US District Court for the Southern District of Texas - 923 F. Supp. 965 (S.D. Tex. 1996), part C. See also Section 1.C., p. 13. As mentioned in here, employer's decisions in recruiting practices also can be evaluated under the disparate treatment and disparate impact theories.

11565 N.Y.2d 213 (1985). https://law.justia.com/cases/new-york/court-of-appeals/1985/65-n-y-2d-2130.html, (date of access 31.7.2020).
} 
upheld after by the Court. However, the Court also mentioned that being obese can be a disability.

In terms of Turkish judicial decisions, I could not find any decision regarding weight discrimination in recruitment. However, as stated above, it is not possible for the employer to discriminate on the basis of weight in recruitment. Furthermore, the applicant cannot enjoy article 5 of the TLA. Instead, the applicant may consult the general provisions within the scope of the law of obligations. ${ }^{116}$

\section{B. In Termination of the Contract}

Several employees who were discriminated against based on their weight also have claimed legal aid via Courts to resolve disputes. In this framework, there are several cases where courts have held whether the termination of the contract is fair.

In the USA, as expressed above, the overweight and obese employees have depended on the ADA for legal protection because of the absence of Acts explicitly prohibiting weight discrimination. ${ }^{117}$ In EEOC v. Resources for Human Development ${ }^{118}$, Harrison (the plaintiff) was hired as a caretaker by the Family House of Louisiana. When she was hired, she was over $180 \mathrm{~kg}$ (more than 400 pounds). Eight years after his employment, her contract was terminated. At that time, she was more than $239 \mathrm{~kg}$ (over 529 pounds). After termination of her contract, EEOC on the behalf of the plaintiff, filed a charge of discrimination alleging that termination was based on her disability due to the weight. The EEOC on behalf of the plaintiff claimed that Harrison's termination was a violation of Title I of the ADA. At the trial, the Court sought answers to all three

\footnotetext{
116 See. paragraph 1 of part 2.

117 ILO, 2013, p. 53.

118827 F. Supp. 2d 688 (2011). https://www.courtlistener.com/opinion/2158112/eeoc-v-resources-forhuman-development-inc/ (Erişim Tarihi: 11.01.2021).
} 
questions. ${ }^{119}$ According to the answers, the Court decided this case felt within the auspices of the ADA. ${ }^{120}$

In the UK, the Case of Walker v. SITA Information Networking Computing Ltd. ${ }^{121}$ is noteworthy. The claimant was $137 \mathrm{~kg}$, and he suffered several diseases such as knee problems, diabetes, high blood pressure, chronic fatigue syndrome because of his alleged weight. He thought he was a disabled person. The first question that arose in the Employment Tribunal was whether he established a physical or mental impairment. The tribunal answered it negatively and decided that the claimant was not disabled; there was no physical or organic cause for his symptoms. However, the Employment Appeal Tribunal's (EAT) verdict was the opposite. EAT also discussed the meaning of disability. According to EAT, the Disability Discrimination Act 1995 does not focus on the cause of impairment; the critical thing is whether the impairment is described as physical or mental. Therefore, the claimant is a disabled person under the Disability Discrimination Act 1995 .

In Turkey, in 2013, the Court of Cassation concludes the termination was unjustified in its verdict. ${ }^{122}$ The plaintiff, who was hired as a cabin crew, alleged that his contract was terminated because of his weight. The defendant requested denial of the case in his statement of defense. According to him, the contract is terminated for a valid reason. Because, although there was a provision about weight limit in the related regulation, the plaintiff did not reach the desired weight level within the given time. Also, his weight

119 For three questions sought by the courts, see. Part 1.C. As mentioned in that part, the three questions are as follows: "Is there a disability within the meaning of the ADA?"; "Is the complaining party a qualified individual with a disability?" and "Did the complaining party suffer an adverse employment decision because of the disability?".

${ }^{120}$ In that case the plaintiff relied on the amendment to the Human Rights Law, also known as The Flynn Act, which prohibited employers from refusing to employ persons with disabilities in New York. At that time the term disability was defined as "a physical, mental or medical impairment resulting from anatomical, physiological or neurological conditions with prevents the exercise of a normal bodily function or is demonstrable by medically accepted clinical or laboratory diagnostic techniques, provided, however, that in all provisions of this article dealing with employment, the term shall be limited to physical, mental or medical conditions which are unrelated to the ability to engage in the activities involved in the job or occupation which a person claiming protection of this article shall be seeking." I should also point out that the ADA entered into force in 1990.

121 Appeal No. UKEAT/0097/12/KN.

122 See. $9^{\text {th }}$ Court of Appeal, 21553/106, Date: 14.1.2013. 
was jeopardizing flight security. In this context, he was dismissed as it was understood that he could not work as a cabin crew at this weight level. According to the first instance court's decision, the employer terminated the contract for no valid reason. In its verdict, the Court stated that "the employer has started to measure employee's weight recently, and these measurements were irregular; there were still overweighed employees who continue to work; there was no evidence whether it jeopardized the flight security; also, weight and height balance is based on visual, besides the employers violated the principle of ultima ratio. After this verdict, the defendant appealed. The $9^{\text {th }}$ Civil Chamber upheld the same decision, which means the contract was terminated for no valid reason.

In 2016, the first instance court ruled that the termination made by the employer was unjust and invalid due to the mobbing in which the employer engaged. ${ }^{123}$ In this context, the court indicated that one of the reasons for the mobbing was the plaintiff's overweight. Besides, according to the decision, even though the employee had resisted to quit despite the pressures, the employer terminated the employment contract. At the stage of appeal, the $9^{\text {th }}$ Civil Chamber reverses the contested judgment due to the first instance court decision established solely on the basis of the witness statement.

In 2018, the plaintiff prevailed in the reinstatement lawsuit. ${ }^{124}$ After this litigation, while the plaintiff was waiting to be reinstated as a security guard at the airport, he was informed that he could not be employed in the related job due to the fact that he did not comply with the height and weight criteria specified in the contract. At this point, the defendant employer offered a job in other workplaces to the plaintiff in accordance with the principle of ultima ratio. However, this proposal, which is a fundamental change in the contract, was not accepted by the plaintiff. In this context, the $22^{\text {nd }}$ Civil Chamber ruled that it could not be mentioned that the employer did not reinstate the plaintiff. Thus, it rejected the claim for employment security compensation.

Within the framework of the cases examined, I have not come across a decision revealing that the employers violate the prohibition of discrimination directly or indirectly

\footnotetext{
123 See. $9^{\text {th }}$ Court of Appeal, 27637/159, Date: 11.1.2016.

124 See. $22^{\text {nd }}$ Court of Appeal, 12880/17455, Date: 9.7.2018.
} 
due to the employees' weight. Accordingly, I was unable to come across any decision confirming that employees whose employment contracts were terminated due to weight were entitled to discrimination compensation. At this point, the first conclusion I draw from the relevant decisions is that employees may be subject to mobbing due to their weight. It shows us that the situation in Turkey is parallel to the other countries where I have stated above. ${ }^{125}$ I also conclude that weight cannot be (or can be) a justified or valid reason for termination. Herein, a conclusion must be reached by scrutinizing the features of each concrete case.

\section{CONCLUSION}

Surveys show us that stigmatization and discrimination because of weight are increasing, especially in the workplace. In recruiting, executing the contract and termination, weight can be a reason for treating differently than non-obese employees. Not only obese or overweight employees but also emaciated employees may face discriminative behaviors.

For restraining discriminative behaviors of employers, States have regulated essential legal documents. Also, international organizations like ILO, EU, UN have adapted provisions and regulations about equality and anti-discrimination.

When we examine these legal documents, it is seen that only a few States excepted the weight as a protected ground against the employer's discriminative activities. In ILO or EU documents, weight is not regulated explicitly as a protected ground. Because of this deficiency, courts have begun to interpret the notion of weight. Besides, in the USA, due to the lack of legal documents forbidding weight discrimination at the federal or state level, weight discrimination has been thought of under the ADA, which means being obese or overweight can be interpreted as a disability. Similarly, in the case of Fag og Arbejde v Kommunernes Landsforening, the CJEU is stated that weight can be a state of disability.

\footnotetext{
125 See. Introduction.
} 
According to Turkish labour law, weight is not explicitly regulated as a ground in the TLA. However, the TLA uses an open system. In the open system, protected grounds have been listed but left open-ended. Based on this, it can be said that weight can be accepted as a ground. On this basis, it is forbidden for the employer to discriminate based on weight. I should also express that it would be more protective to use open-ended system in the AHREIT, international and the other national labour law.

Finally, the employee's weight can also be considered as a disability in Turkish labour law. The primary Act about disability is ADP. Under the provisions in the ADP, the disabled person is defined. Also, in the AHREIT, the same definition can be found. Within the framework of this definition, I may accept the obese individual as disabled. In other words, if an obese, overweight or emaciated employee fulfills conditions that are expressed in the Acts, he/she may now be considered a disabled employee. 


\section{BIBLIOGRAPHY}

BAJOREK, Zofia / BEVAN, Stephen, "Obesity and Work Challenging Stigma and Discrimination”, Institute for Employment Issue, Year: 2019, Report 526.

BAKIRCI, Kadriye, "Eşitlik Kurulu Kanunu ile Anayasa ve İş Kanunu'nun İlgili Hükümleri Üzerine Bir Değerlendirme", Emeğin Hukuku Kurultayı 2, Türkiye Barolar Birliği Yayın1, Ankara, Year: 2017, (p. 65-75).

BAKIRCI, Kadriye, "İş Güvencesi Kapsamındaki İşçilerin Doğrudan Tazminat Talep Hakları ve Kötüniyet veya Sendikal Tazminat ile Ayrımcılık Tazminatı İlişkisi”, Sicil İş Hukuku Dergisi, Year: 2006, Volume: 2, (p. 114-121).

BAKIRCI, Kadriye, Uluslararası Hukuk, AB ve ABD Hukuku ile Karşılaştırmalı Çalışma Yaşamında Kadın Erkek Eşitliği Arayışı Cinsiyet Ayrımcılığı Yasağı ve Türkiye, Seçkin Yayınevi, İstanbul, 2012 (a).

BAKIRCI, Kadriye, Uluslararası Hukuk, AB ve ABD Hukuku ile Karşılaştırmalı İş Hukukunda Cinsiyet Ayrımcılığı Yasağı İlkesinin İstisnaları ve Objektif Haklı Nedenler, Seçkin Yayınevi, İstanbul, 2012 (b).

BAŞBUĞ, Aydın / YÜCEL BODUR, Mehtap, İş Hukuku, Beta Yayınevi, İstanbul, 2018.

BIERMAN Jr., Donald L., "Employment Discrimination Against Overweight Individuals: Should Obesity Be Protected Classification", Santa Clara Law Review, Year: 1990, Volume:30, Issue:4, (p. 951-976).

BOURBON, Alexandra, "Fag og Aberjde (FOA) v. Kommunernes Landsforening (KL): Will Expanding the Definition of Disability to Include Obesity Lead to an Expanding Waistline in Europe", Tulane Journal of International and Comparative Law, Year: 2016, Volume: 24, Issue: 2, (p. 351-370).

CAVICO, Frank J. / MUFFLER, Stephen C. / MUJTABA, Bahaudin G., "Appearance Discrimination, "Lookism" and "Lookphobia" in the Workplace", The Journal of Applied Business Research, Year: 2012, Volume: 28, Issue: 5, (p. 791-802).

CENTEL, Tankut, İş Güvencesi, Legal Yayınevi, İstanbul, 2020.

CHERNOV, Andrea E., "Weight Discrimination: The Effects of Obesity on Employment and Promotion", University of Hawaii Hohonu, Year: 2006, Issue: 6, (p. 107-113).

CORBERTT, William R., "Hotness Discrimination: Appearance Discrimination as a Mirror for Reflecting on the Body of Employment-Discrimination Law", Catholic University Law Review, Year: 2011, Volume: 60, Issue: 3, (p. 615-660).

ÇELIK, Nuri / CANIKLİĞLU, Nurşen / CANBOLAT, Talat, İş Hukuku Dersleri, Beta Yayınevi, İstanbul, 2019.

DEĞİRMENCİ, Taner / KALKAN OĞUZHANOĞLU, Nalan / SÖZERİ VARMA, Gülfizar $e t$. all., "Psychological Symptoms in Obesity and Related Factors", Arch Neuropsychiatry, Year: 2015, Volume: 52, (p. 42-46). 
DOELLMAN, David A., "Statutory Leapfrog: Compensatory and Punitive Damages under the Retaliatory Provision of the ADA", Missouri Law Review, Year: 2009, Volume: 74, Issue: 1, (p. 173-191).

DOĞAN, Gülmelahat, "Ayrımcılık Tazminatı-Sendikal Tazminat (Dayandıkları Esaslar ve Farkl111kları)”, Ankara Bar Review, Year: 2014, Issue: 1, (p. 361-390).

DOĞAN YENISEY, Kübra, "İş Kanununda Eşitlik İlkesi ve Ayırımcılık Yasağı”, Çalışma ve Toplum Dergisi, Year: 2006, Issue: 4, (p. 63-82).

EKMEKÇİ, Ömer / KORKUSUZ, Refik, Turkish Individual Labour Law, 12 Levha Yayınc1lı, İstanbul, 2020.

EKMEKÇİ, Ömer / YİĞİT, Esra, Bireysel İş Hukuku Dersleri, 12 Levha Yayınc1lık, İstanbul, 2020.

EUROPEAN AGENCY FOR FUNDAMENTAL RIGHTS, Handbook on European NonDiscrimination Law, 2018, https://fra.europa.eu/sites/default/files/fra_uploads/1510FRA-CASE-LAW-HANDBOOK_EN.pdf, (date of access 2.8.2020).

FAVALLI, Silvia / FERRI, Delia, "Tracing the Boundaries Between Disability and Sickness in the European Union: Squaring the Circle", European Journal of Health Law, Year: 2006, Volume: 23, Issue: 1, (p. 5-35).

FLINT, Stuart W. / CODREANU, Sonia C. / GOMOIU, Amalia et al., "Obesity Discrimination in the Workplace: "You're Hired!"”, Journal of European Psychology Students, Year: 2015, Volume: 6, Issue: 2, (p. 64-69).

FLINT, Sturart W. / SNOOK, Jereme, "Obesity and Discrimination: The Next Big Issue", International Journal of Discrimination and the Law, Year: 2014, Volume: 14, Issue: 3, (p. 183-193).

GARCIA, Jeffrey, "Weight-Based Discrimination and the Americans With Disability Act: Is There an End in Sight?", Hofstra Labor and Employment Law Journal, Year: 1995, Volume: 13, Issue: 1, (p. 1-30).

GÜVEN, Ercan / AYDIN, Ufuk, Bireysel İş Hukuku, Nisan Kitapevi, Eskişehir, 2020.

HUGGINS, Michael L., "Not Fit for Hire: The United States and France on Weight Discrimination in Employment", Fordham International Law Journal, Year: 2015, Volume: 38, Issue: 3, (p. 889-951).

HUXLEY, Caroline, "Lesbian and Bisexual Women's Experiences of Sexuality-Based Discrimination and Their Appearance Concern", Psychology \& Sexuality, Year: 2012, Volume: 4, Issue: 1, (p. 7-15).

ILO, Discrimination at Work on the basis of Sexual Orientation and Gender Identity: Results of Pilot Research, International Labour Office, Governing Body, 319th Session, Genova, 2013. 
https://www.ilo.org/wcmsp5/groups/public/---ed_norm/---

relconf/documents/meetingdocument/wcms_221728.pdf, (date of access 29.8.2020).

JOLLY-RYAN, Jennifer, "Have a Job to Get a Job: Disparate Treatment and Disparate Impact of the 'Currently Employed' Requirement", Michigan Journal of Race and Law, Year: 20212, Volume: 12, (p. 189-212).

KANDEMIR, Murat / YARDIMCIOĞLU, Didem, "İş Hukukunda Eşitlik İlkesi”, Journal of the Faculty of Law Dicle University, Year: 2014, Volume: 19, Issue: 30-31, (p. 1-44).

KARAGÖZ, Veli, "İş Hukukunda Ayrımcılık Tazminatı", Erzincan Üniversitesi Sosyal Bilimler Enstitüsü Dergisi, Year: 2012, Issue: 1, (p. 57-76).

KARAN, Ulaş, Uluslararası İnsan Hakları Hukuku ve Anayasa Hukuku Işığında Eşitlik İlkesi ve Ayrımcılık Yasağı, 12 Levha Yayınevi, İstanbul, 2017.

KESER, Hakan, "4857 Sayı1ı İK'na Göre İşverenin İş Sözleşmesi Yapma ve İş İlişkilerinde Eşit İşlem Yapma Yükümlülükleri ve Bunlara Aykırı Davranması Durumunda Karşılaşacağ Yaptırımlar", Kamu İş Dergisi, Year: 2004, Volume: 7, Issue: 3, (p. 1-38).

KRISTEN, Elizabeth, "Addressing the Problem of Weight Discrimination in Employment", California Law Review, Year: 2002, Volume: 90, Issue: 1, (p. 57-110).

KUBOTA, Luis Claudio, "Discrimination Against the Obese and Very Thin Students in Brazilian Schools", Institute for Applied Economic Research, Discussion Paper 199, 2015, http://repositorio.ipea.gov.br/bitstream/11058/5138/1/DiscussionPaper_199.pdf, (date of access 10.9.2020).

LEE, Hyemin / SON, Inseo / YOON, Jaehong et al., "Lookism Hurts: Appearance Discrimination and Self-Rated Health in South Korea" International Journal for Equity in Health, Year: 2017, Issue: 16, (p. 204-210).

MAHAJAN, Ritu, "The Naked Truth: Appearance Discrimination, Employment, and the Law", Asian American Law Journal, Year: 2007, Volume: 14, (p. 165-204).

MALOS, Stan, "Appearance-Based Sex Discrimination and Stereotyping in the Workplace: Whose Conduct Should We Regulate?", Employee Responsibilities Rights Journal, Year: 2007, Issue: 19, (p. 95-111).

MASON, Katherine, "The Unequal Weight of Discrimination: Gender, Body Size, and Income Inequality”, Social Problems, Year: 2015, Volume: 59, Issue: 3, (p. 411-435).

MCCOY, Maura Flaherty, "Classifying Obesity as Disability Under the Americans With Disability Act: How Seff v. Broward County in Incongruent with Recent ADA Litigation", Catholic University Law Review, Year: 2015, Volume: 64, Issue: 2, (p. 539-562).

MCCRUDDEN, Christopher / PRECHAL, Sacha, "The Concepts of Equality and NonDiscrimination in Europe: A Practical Approach", European Commission DirectorateGeneral for Employment, Social Affairs and Equal Opportunities, Unit G. 2, Year: 2009. 
O'BRIEN, Kerry Steven / LATNER, Janet / EBNETER, Daria et al., "Obesity Discrimination: The Role of Physical Appearance, Personal Ideology, and Anti-Fat Prejudice", International Journal of Obesity, Year: 2013, Issue: 37, (p. 455-446).

ODAMAN, Serkan, “Ayrımcılık Tazminatının Diğer Tazminatlarla Birlikte Mevcudiyeti Sorunu Üzerine Görüşler”, Sicil İş Hukuku Dergisi, Year: 2009, Volume: 14, (p. 77-83).

ODYAKMAZ, Zehra / KESKİN, Bayram / DENIZ, Yusuf, "6701 Sayılı Türkiye İnsan Hakları ve Eşitlik Kurumu Kanunu Üzerine Bir Değerlendirme - I”, Uyuşmazlık Mahkemesi Dergisi, Year: 2016, Issue: 71, (p. 721-761).

PUHL, Rebecca M. / DEPIERRE, Jenny A., “Appearance Discrimination and The Law”, Encyclopedia of Body Image and Human Appearance, Year: 2012, Volume: 1, (p. 30$35)$.

RHODE, Deborah L., "The Injustice of Appearance", Stanford Law Review, Year: 2009, Volume: 61, Issue: 5, (p. 1033-1102).

SENYEN KAPLAN, Emine Tuncay, Bireysel İş Hukuku, Gazi Kitapevi, Ankara, 2019.

SENYEN KAPLAN, Emine Tuncay, "İş Hukukunda Eşitlik İlkesi ve Cinsiyet Ayrımı”, Türkiye Barolar Birliği Dergisi, Year: 2017, Special Issue, (p. 225-268).

SHINALL, Jennifer Bennet, "Distaste or Disability: Evaluating the Legal Framework for Protecting Obese Workers", Berkeley Journal of Employment and Labour Law, Year: 2006, Volume: 37, Issue: 1, (p. 101-142).

SIZEMORE, Steven C., "Fatter Butt Equals a Skinnier Wallet: Why Workplace Wellness Programs Discriminate Against the Obese and Violate Federal Employment Law", Wyoming Law Review, Year: 2011, Volume: 11, Issue: 2, (p. 639-668).

SUR, Melda, "İ İlişskisinde Eşitlik İlkesi ve Ayrımcılık Yasağı", Sicil İş Hukuku Dergisi, Year: 2017, Issue: 37, (p. 33-51).

SÜZEK, Sarper, İş Hukuku, Beta Yayınevi, İstanbul, 2020.

SWAMI, Viren / WONG, Vivien / FURNHAM, Adrian et. all, "Weight-Based Discrimination in Occupational Hiring and Helping Behavior", Journal of Applied Social Psychology, Year: 2008, Volume: 38, Issue: 4, (p. 968-981).

TAŞDEMİR, Yasemin, “İş Hukukunda Genetik Ayrımcılık Yasağı”, Dokuz Eylül Üniversitesi Hukuk Fakültesi Dergisi, Year: 2020, Issue:22, Volume: 2, (p. 947-990).

TIMMER, Alexandra / SENDEN, Linda, Gender Equality Law in Europe-How are EU Rules Transposed into National Law in 2016, Luxemburg: Publications Office of the European Union, 2016.

TUNCAY, A. Can, "Birden Fazla Tazminat Kapsamına Giren Eylemde Hangi Tazminata Hükmedilecektir?”, Sicil İş Hukuku Dergisi, Year: 2008, Volume: 10, (p. 105-110). 
TUNÇOMAĞ, Kenan / CENTEL, Tankut, İş Hukukunun Esasları, Beta Yayınevi, İstanbul, 2018.

VIVIERS, Damien Jr., A Comparative Labour Law Perspective on Categories of Appearance-Based Prejudice in Employment, Unpublished Thesis (LL.M), University of the Free State, 2014.

ÜNAL, Canan, "Engellilik Kavramının ve Engellilerin Sosyal Güvenlik Haklarının Uluslararası ve Karşılaştırmalı Hukuk Işı̆̆ında Değerlendirilmesi”, MÜHF Engelli Hakları Komisyonu Engelli Hukukuna Giriş Sempozyumu, Legal Yayıncılık, İstanbul, 2015.

ÜNAL, Canan, İş Hukukunda Yaş Ayrımcılığı,12 Levha Yayıncılık, İstanbul, 2018.

WANG, Lucy, "Weight Discrimination: One Size Fits All Remedy?", The Yale Law Journal, Year: 2008, Issue: 117, (p. 1900-1945).

YILDIZ, Gaye Burcu, "Türk İş Hukukunda Özürlülük ve Sağlık Durumuna Dayalı Ayrımcılık Yasağı”, Sicil İş Hukuku Dergisi, Year: 2008, Issue: 10, (p. 80-88). 